
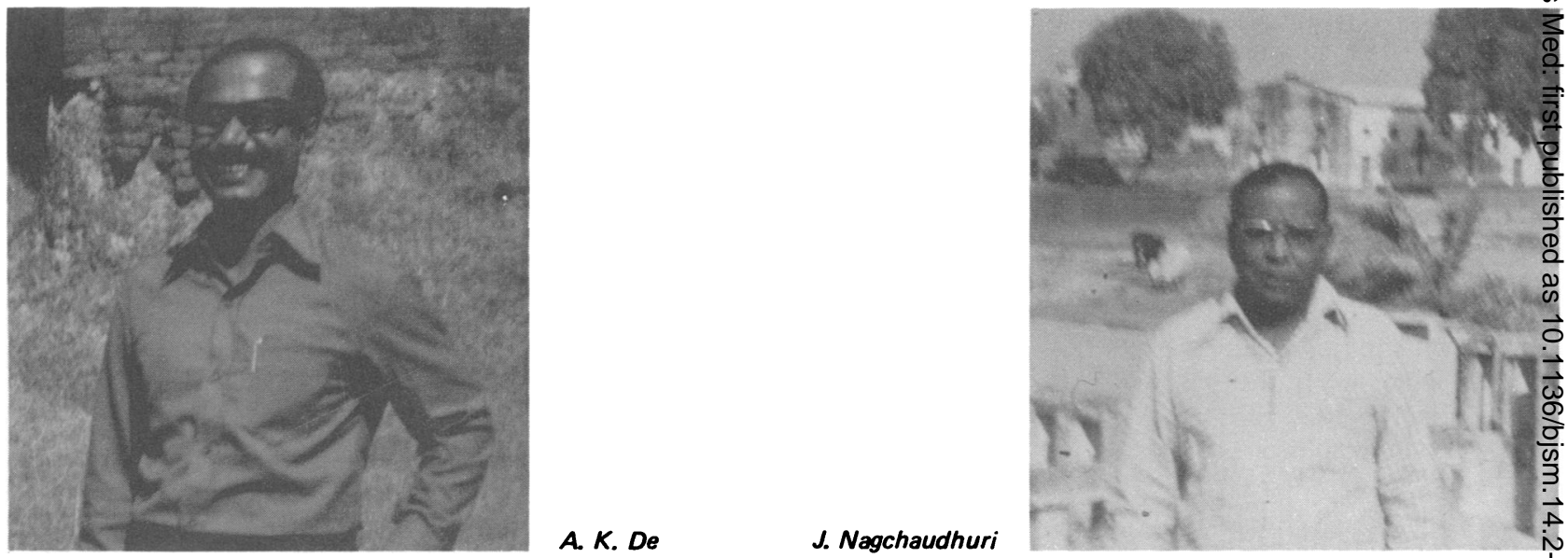

\title{
RESPIRATORY PERFORMANCE AND GRIP STRENGTH TESTS IN INDIAN SCHOOL BOYS OF DIFFERENT SOCIO-ECONOMIC STATUS
}

A. K. DE, DCH, MD, ${ }^{*}$ P. K. DEBNATH, PhD, ${ }^{* *}$ N. K. DEY, MA, ${ }^{* * *}$ and J. NAGCHAUDHURI, MB, BS, PhD*

*Unit of Sports Medicine and Pulmonary Physiology, Department of Physiology, Institute of Medical Sciences, Banaras Hindu University, VARANASI - 221005, INDIA

* *Department of Kayachikitsa (Internal Medicine), J. B. Roy State Ayurvedic Medical College and Hospital, 170-172, Raja Dinendra Street, CALCUTTA - 700 004, INDIA

*** Rajbalhat High School, Hooghly District, WEST BENGAL, INDIA \begin{abstract}
physical activity employing the arm muscles.
\section{INTRODUCTION}

The energy required for the performance of physical work is ultimately derived from the food. It is well appreciated that the capacity of an organism to accomplish physical work deteriorates with continued calorie undernutrition. Moreover, subnutrition delays growth during childhood as well as the onset of the adolescent growth spurt. In man, this fact is well documentated from the effects of famine due to various causes (Wolf, 1935; Ellis, 1945; Howe and Schiller, 1952; Kimura et al, 1959).
\end{abstract}

ABSTRACT

Physical efficiency tests were performed on urban school boys drawn from higher socio-economic status in compariso to rural school boys. The height and weight records of the subjects indicating growth process showed that the rura boys attained less physical growth than their urban counterparts. The Vital Capacity and Peak Expiratory Flow Rate data expressed either per unit of height or body surface area were significantly lower in rural boys. These findings indicated a poor development of the thorax in the rural group. However, the determined grip strengths for both the groups were similar. The grip test might reflect improvement of muscle mass in case of rural boys as a result of regular

An important variable in the physical performance of the population is the socio-economic status, especially the state of nutrition. It has also been reported that the growth differences were more closely related to home conditions than to the strictly economic status of they families (Bransby et al, 1946; Abramson and Ernest్ 1954; Scott, 1961). Other experiments on work performance conducted on healthy volunteers kept i starved or semi-starved conditions were shown to cause the reduction of performance capability (Keys et aff 1950). However, a major problem of a vast number of populations in under-developed and developing countries is the restricted protein and calorie intake from childhood. There is a paucity of literature with deteB minations of physical efficiency levels of adolescen who are in a continuous state of subnutrition since theip childhood (Areskog et al, 1969; Bisht et al, 1972t 
This study was thus undertaken on the Indian adolescent boys to assess the influences of nutritional status and socio-economic level on growth and some physical performance capabilities.

\section{MATERIALS AND METHODS}

Eighteen boys from an urban school (Calcutta, West Bengal) and nineteen boys from a rural school (Rajbalhat Village, District of Hooghly, West Bengal) were selected for this study, aged between 10 and 14 years. The urban school students were from comparatively higher socioeconomic status than the rural boys, belonging to families of an income group between Rupees $1,000 /$ to $1,400 /$ - whereas the rural boys were from families with an income range between Rupees $300 \%$ to $500 /$ per month ( $f 1 \cong R s$ 18). The dietary surveys of the experimental subjects were carried out by the questionnaire technique of Madhavan and Swaminathan, (1966). From early childhood there were more frequent gastro-intestinal upsets and minor febrile illnesses in the rural group. The height and weight of the subjects were recorded and the surface area was determined following Dubois nomogram (Vijayaraghavan et al, 1971 a, b). Vital capacity (VC) and Peak Expiratory Flow Rate (PEFR) were measured by using Wright's Respirometer (BOC, England) and Wright's Peak Flowmeter (Clement Clarke International Ltd.) respectively. Grip Strength (GS) was determined for both the hands using Hand-Dynamometer (Anand Agencies, India). All the tests were done at least three times allowing a reasonable time internal of approximately $5 \mathrm{~min}$ between tests, and the highest result was accepted. The values of VC and PEFR were corrected to BTPS.

TABLE I

Data showing the age, physical characteristics and grip strength of the subjects.

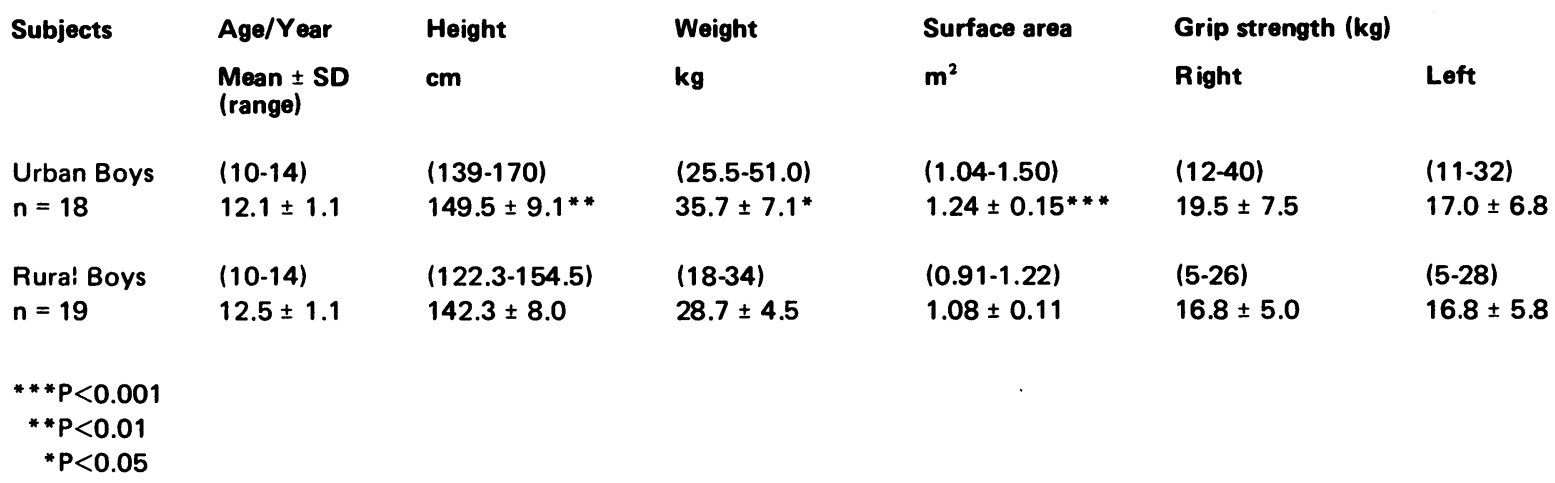

TABLE II

Data showing the results of Vital Capacity and Peak Expiratory Flow Rate.

\begin{tabular}{|c|c|c|c|c|c|c|c|c|}
\hline \multirow{3}{*}{ Subject } & \multicolumn{3}{|c|}{ VITAL CAPACITY } & \multicolumn{4}{|c|}{ PEAK EXPIRATORY FLOW RATE } & \multirow[b]{2}{*}{ L/yr of age } \\
\hline & $\begin{array}{l}\text { Total } \\
\text { litres }\end{array}$ & $\underset{\text { height }}{\mathrm{ml} / \mathrm{cm}}$ of & $\begin{array}{l}\mathrm{L} / \mathrm{m}^{2} \text { of } \\
\text { surface } \\
\text { area }\end{array}$ & $\begin{array}{l}\text { Total } \\
\text { (L/min) }\end{array}$ & $\begin{array}{l}\text { L/cm of } \\
\text { height }\end{array}$ & $\begin{array}{l}\text { L/kg of } \\
\text { weight }\end{array}$ & $\begin{array}{l}\mathrm{L} / \mathrm{m}^{2} \text { of } \\
\text { surface } \\
\text { area }\end{array}$ & \\
\hline & & $\underset{\text { (range) }}{\text { Mean } \pm \text { SD }}$ & & & & & & \\
\hline Urban Boys & $(1.80-3.40)$ & $(12.95-21.93)$ & $(1.67-2.48)$ & $(235-465)$ & $(1.7-2.9)$ & $(7.4-12.8)$ & $(224.6-349.1)$ & $(22.9-35.8)$ \\
\hline$n=18$ & $2.41 \pm 0.46^{* * *}$ & $16.04 \pm 2.32^{* * *}$ & $1.94 \pm 0.22^{* *}$ & $351.4 \pm 68.8^{* *}$ & $2.34 \pm 0.4^{*}$ & $9.92 \pm 1.4^{*}$ & $283.8 \pm 39.8$ & $28.9 \pm 4.3^{* * * *}$ \\
\hline Rural Boys & $(1.60-2.50)$ & $(10.85-16.67)$ & $(1.61-2.12)$ & $(242-348)$ & $(1.6-2.7)$ & $(9.5-14.2)$ & $(221.8-409.6)$ & $(18.9-30.0)$ \\
\hline$n=19$ & $1.93 \pm 0.30$ & $13.61 \pm 1.74$ & $1.79 \pm 0.24$ & $304.0 \pm 39.5$ & $2.14 \pm 0.3$ & $10.8 \pm 1.7$ & $284.5 \pm 42.7$ & $24.3 \pm 2.5$ \\
\hline
\end{tabular}




\section{RESULTS AND DISCUSSION}

The results are summarised in Tables | \& II.

The records of height and weight of the subjects indicating the growth process show that the rural boys attained less physical growth than the urban boys (Table 1), and had a smaller surface area. This development in the higher socio-economic group has been reported by several workers as well (Meredith, 1951; Berry and Cowin, 1954; De and Nagchaudhuri, 1976). The past history of the experimental subjects and their dietary intake reflected the poor health status of the rural boys as against those from the urban area. Similar observations have also been reported by various other authors (Berry and Cowin, 1954; Benech et al, 1960; Scott, 1961; Sastry and Srikantia, 1975; Rao and Satyanarayana, 1976 a, b).

The mean vital capacity, either expressed per unit height or per unit body surface area was significantly lower in the rural group of boys from that of the urban group (Table II). The PEFR (Expressed per unit height or unit surface area), an indicative of the performance of respiratory muscles and status of elastic tissue in the lungs, was significantly higher in the urban group than that of the rural group. The obvious conclusion that could be drawn from these findings indicate a poor development of respiratory muscles in rural group. However, whether the development of elastic tissue of the lung was also affected or not has to await further experiment.
Although the performance level of the skeletal $\frac{\text { के }}{3}$ musculature of the urban boys by using hand dynamo- $\stackrel{\mathbb{2}}{\Omega}$ meter, was slightly more than those of the rural boys, the difference was not statistically significant. The present experiments revealed an inferior work $\overline{0}$ performance of the respiratory muscles in rural boys but $\frac{\bar{\sigma}}{\bar{\sigma}}$ not of arm muscles. The explanation of the findings lies $\frac{\bar{p}}{\bar{p}}$ in the social living of the rural boys who had to use their $\stackrel{\Phi}{\Omega}$ arm muscles to provide help either in cultivation or in weaving etc, whereas the urban children do not perform s muscular work using hand muscles. The grip test method $\vec{\circ}$ therefore, may reflect improvement of muscle mass in $\overrightarrow{\vec{\omega}}$ the rural boys as a result of regular physical activity $\stackrel{\sigma}{\sigma}$ employing the arm muscles.

Similar studies on 10 year old boys carried out in Paris, have shown lower values of vital capacity of the boys who had relatively less height and also significantly $\dot{\omega}$ lower arm muscle strength by grip test (Benech et $\vec{A}$ al, 1960). The rural group in the present study may or simulate the physical performance level of the Paris 옹 group reported above with a significant difference from that group in the arm muscle performance. This difference may be related to the occupational situations being different in these two groups.

The respiratory performance test of the present study of the rural boys, obviously less nourished than their urban counterpart showed values of these tests which were similar to those reported under-nourished age group of subjects. (Bisht et al, 1969; Areskog et al, 1969; De et al, 1978).

\section{REFERENCES}

Abramson, E. and Ernest, E. 1954. Height and Weight of school boys at a Stockholm Secondary School, 1950, and a comparison with earlier investigations. Acta.Paediat. (Upsala), 43, 235-46.

Areskog, N. H., Selinus, R. and Vahliquist. 1969. Physical work capacity and nutritional status in Ethiopian male children and young adults. Am.J.Clin.Nutr. 22, 471-79.

Benech, A., Mathieu, B. and Schreider, E. 1960. Dimensions de la famille et caracteres biologiques des enfants. Biotypologie, 21, 1-33.

Bery, W. T. C. and Cowin, P. J. 1954. Conditions associated with the growth of boys, 1950-51. Brit.Med.J. 1, 847-51. స్

Bisht, D. B. and Krishnamurthy, M. 1972. Exercise tolerance and work capacity in primary malnutrition. Indian Heart $\mathcal{N}_{\mathcal{E}}^{N}$ J. 24, 352-64.

Bransby, E. R., Burn, J. L., Magee, H. E. and Mackecknie, D. M. 1946. Effect of certain social conditions on the health of school children. Brit.Med.J 2, 767-9.

De, A. K. and Nagchaudhuri, J. 1976. Studies on the Basal Metabolic Rate-boys and girls. Indian J.Med.Res. 64, 584-89.

De, A. K., Debnath, P. K., Roy, D. C. and Nagchaudhuri, J. 1978. A comparison of Physical efficiency between Indian Physical Education and Medical Students. Brit.J.Sports Med. 12, 93-6. 
Ellis, R. W. B. 1945. Growth and health of Belgium children during and after the German occupation, $1940-44$. Arch.Dis.Childh. 20, 97-109.

Howe, P. E. and Schiller, M. 1952. Growth responses of the school child to changes in diet and environment factors. J.Appl. Physiol. 5, 51-61.

Keys, A., Bozek, J., Henschel, A. and Taylor, H. L. 1950. Biology of Human Starvation. Vol. I. Oxford Univ. Press. Chapter, 15, 20, 27 and 34.

Kimura, K., Hagiya, S. and Kitano, S. 1959. Effect of war on strature. Zinring. Zassi. 67, 82-9.

Madhavan, S. and Swaminathan, M. C. 1966. A comparative study of two methods of diet survey. Indian J.Med.Res. 54, 480-85.

Meredith, H. V. 1951. Relations between socio-economic status and body size in boys seven to ten years of age. Am.J. Dis.Child. 82, 702-9.

Rao, H. and Satyanarayana, D. K. 1976 a. Nutritional status of people of different socioeconomic groups in a rural area with special reference to pre-school children. Ecol.Fd.Nutr. 4, $237-42$.

Rao, H., Satyanarayana, D. K. and Sastry, G. 1976 b. Growth pattern of well-to-do Hydrabad pre-school children. Indian J. Med.Res. 64, 629-38.

Sastry, G. and Srikantia, S. G. 1976. Using heights and weights, how close are our estimates of undernutrition in a community? Indian J.Med.Res. 64, 193-98.

Scott, J. A. 1961. Report on the heights and weights (and other measurements) of school pupils in the county of London in 1959. London: County Council.

Vijayaraghavan, K., Singh, D. and Swaminathan, M. C. 1971 a. Heights and weights of well nourished Indian school children. Indian J.Med.Res. 59, 648-658.

Vijayaraghavan, K., Sastry, G. and Jindal, I. B. 1971 b. Growth performance of well to do Hyderabad children - a follow-up study. Indian J.Med.Res. 62, 117-24.

Wolf, G. 1935. Increased bodily growth of school-children since the war. Lancet, I, 1006-11. 